\title{
MIND THE GAP: SECOND LANGUAGE ACQUISITION COMES OF AGE IN A DIGITAL WORLD
}

\author{
Zarina M. Charlesworth ${ }^{1}$, Cédric Baudet ${ }^{2}$ \\ ${ }^{1 / 2}$ HES-SO University of Applied Sciences \& Arts Western Switzerland, SWITZERLAND
}

\begin{abstract}
This paper presents an in-depth case study of an English language provider, its specific in-context method of teaching English as foreign language, and the evolution that has occurred through advances in technology. The introduction of technological innovation and barriers to acceptance as well as influencing variables are examined in light of the past, present, and future. Initial findings suggest that a key factor to success is related to the timeliness of introduction of the new technology in combination with variables previously identified in the Unified Theory of Acceptance and Use of Technology (UTAUT). The paper closes with suggestions related to the introduction of innovative technologies.
\end{abstract}

Keywords: Innovation, Technology, Second language acquisition, Virtual reality

\section{INTRODUCTION}

"Could you teach English?" A split second of hesitation later and Gordon replied "Yes, of course". A first experience in the Swiss public-school system in 1984 and the basis for what would later become English in Context started to take root as Gordon began to develop his own method for teaching English as a foreign language. Who has never felt the frustration of being in a foreign language situation, be it private or professional, and not understanding what is being said - and this frequently after months of language training? Countless hours are spent in the classroom preparing for language exams to little avail when it comes to using the language. Discouraged by the methods that he was asked to use, Gordon left the school system and set up shop on his own two years later. This paper provides an in-depth look at the past, present, and future practices of a specific English Language provider where the use of in-context learning has not only developed over time but also weathered the introduction of more than one technological innovation. An analysis of the diffusion of innovation in the realm of language learning with an emphasis on the barriers to acceptance follows. Lessons are taken from past experience to look towards the successful integration of future technological developments.

As the tsunami of the $4^{\text {th }}$ industrial revolution [1] breaks on the shores of the $21^{\text {st }}$ century only those industries ready for its impact will survive and thrive. With unprecedented demand for their services, those involved in the teaching of English as a second language are at the front of this wave. Market estimates for the global, academic plus non-academic, English language learning sector put it at up to US\$ 63.3 billion for 2013 within which the digital language learning segment accounts for 5\% [2, 3]. Within this sector the highest demand is currently coming from China, Asia and, Africa, however, even Western Europe is expected to to show an estimated 5-year Compound Annual Growth Rate (CAGR) of $4.5 \%$ taking the 2013 digital English language market figures from US $\$ 343.8$ million to US $\$ 428.6$ million by 2018 [3]. English has not only reinforced its position as an international language with the advent of globalization and the use of the internet but is also now being taught from the primary school level on up and is increasingly the language of instruction in universities around the world.

This project is concerned with how best to weather technological change resulting in the acceptation and further diffusion of technology when significant future technological change is on the horizon through the introduction of virtual reality as a tool for second language acquisition

\section{LITERATURE REVIEW}

The literature referred to in this research draws on two streams, one being that of second language acquisition and the other that of the acceptance of technological innovation. Educational approaches and models are continually undergoing revision, but today's educational paradigms are evolving at an unprecedented speed coupled with technological developments. Accordingly, a review of the principle 
developments in second language acquisition over time followed by a brief review of models pertaining to the acceptance of technological innovation are presented in the subsections below.

\subsection{Second language acquisition}

The teaching of English as a foreign language grew into its own in the $20^{\text {th }}$ century when the debate about the theoretical foundations of language teaching methods were laid, drawing on the work of linguists and psychologists $[4,5]$.

Research in second language acquisition clearly shows that the 'drill and rote' learning of the 1970's followed by the communicative approach and then the later task-based orientation of the 1990's do not adequately address the needs of today's language learners and it is only in the past twenty years that the idea of in-context learning has even taken hold.

Historically, learning a second language has undergone various influences on the approaches and methods used [6]. From as far back as the Middle Ages and through the 1800's, two major approaches to language learning can be identified, that of grammar-translation which focused on analysing the language and, a less frequent approach based on language use. It was, however, the grammar-translation method that remained the dominant approach as it was the standard method used in schools and universities. Despite the introduction of other approaches that stressed language use, such as the Direct Method, the Reading Approach for example, the grammar-translation approach held its own until the 1940's when a need for language use, especially by those in the U.S. armed forces, changed the imperative. It was at this time that the theoretical foundations of language teaching methods were laid, drawing on the work of linguists and psychologists [4,5]. This led to the development of the Audio-Lingual approach in the United States and concurrently to the Situational Approach in Great Britain, followed by a number of other approaches that emphasized comprehension and communication.

Language teachers today have any number of methods, approaches, and techniques to choose from. Their choice may be dictated by the context in which the instruction is given, the school, the learners, or simply due to individual preference. It is not the intention of this very brief review to suggest that any one approach is the best rather simply to make the reader aware of the multiplicity that language teachers today are faced with and to call to the reader's attention changes in society that have and still are having a real impact on the demand for language instruction. Changes that include the massification of travel, a continued rise in study abroad programs, the rise of multinationals, the use of internet and music platforms such as Spotify, just to name a few.

Adding to the complexity of the afore-mentioned is the advent of digital / mobile technologies which is what brings us to the second body of literature that we are drawing on, the acceptance of technological innovation.

\subsection{Diffusion and acceptance of technological innovation}

Two of the key issues related to innovation are its diffusion and long-term adoption. Drawing on wellestablished models Abernathy and Utterback [7] and Rogers [8], the main objective of this project is the identification of strategies to prevent a fall into the chasm as described by Rogers [8] that exists between the early adopters of a new technology and the considerably larger market of early users. In order to better understand the variables involved in the acceptance of new technology we turn to Venkatesh et al. and their work on the Unified Theory of Acceptance and Use of Technology (UTAUT) $[9,10]$. Although subsequent work has been done on the original model, we have chosen to use the original four variables identified, shown in Table 1, applying them to the acceptance of new technology

Table 1. UTAUT Variables Based on Venkatesh et al. [9] and cited in Dwivedi et al. [11]

\begin{tabular}{l|l}
\hline \hline Performance Expectancy (PE) & $\begin{array}{l}\text { The degree to which an individual believes that using the proposed } \\
\text { technology will allow for gains in job performance }\end{array}$ \\
\hline Effort Expectancy (EE) & The degree of ease associated with the use of the technology \\
\hline Social Influence (SI) & $\begin{array}{l}\text { The degree to which an individual perceives that those of } \\
\text { importance feel the technology should be adopted or used }\end{array}$ \\
\hline Facilitating Conditions (FC) & $\begin{array}{l}\text { The degree to which an individual believes that an organizational } \\
\text { and technical infrastructure exists to support the use of the system }\end{array}$ \\
\hline \hline
\end{tabular}


and not just to information systems as was initially intended. In addition to the afore-mentioned variables, one other important element relating to the acceptance of technology can be illustrated with Gartner's Hype Cycle shown below in Figure 1.

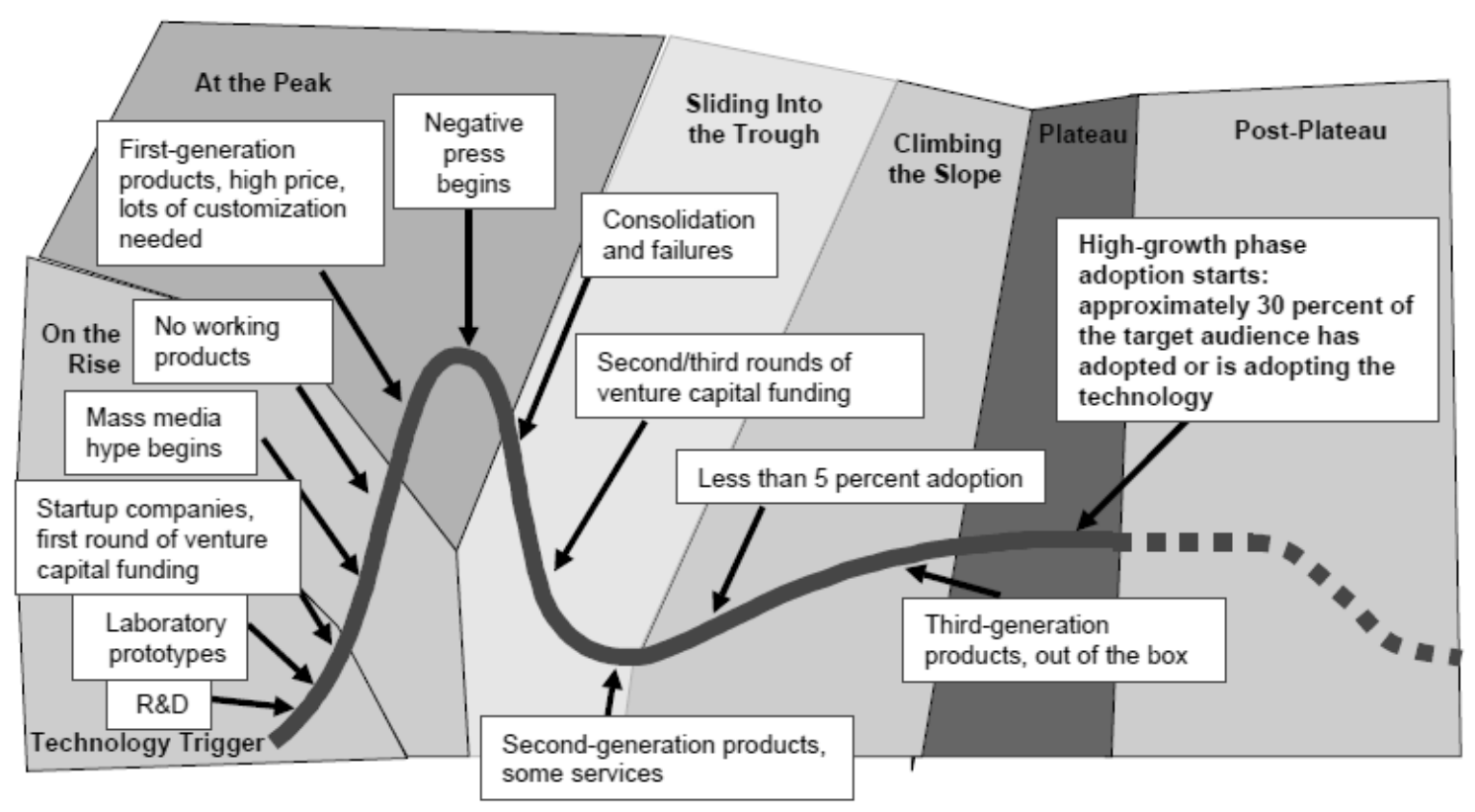

Figure 1. Gartner's Hype Cycle [12]

The point of interest here is around the time of consolidation and failures combined with the second / third rounds of capital funding. It is at this time that relatively new technologies start to become available to a larger public. At this stage we are still looking at early adopters, but the early users are not far off. Our interest is looking at a specific market through the eyes of one English language provider and evaluating what has allowed for success upon success each time a new technology has been introduced.

With this in mind the following research questions were formulated to help contextualise the project.

How can the introduction of new and sometimes disruptive technologies be navigated?

How can barriers to the introduction of new technology be overcome?

How might the following variables: performance expectancy; effort expectancy; social influence; facilitating conditions; playing a role in the acceptance of new technology?

\section{METHODOLOGY}

A multiple-technique ethnographic case study approach was selected to provide an in depth look at the past, present and future practices of a selected English language provider, English in Context. As our questions were essentially "how" questions, the choice of the case study method became clear [13]. The rationale for using a single case for study was that due to the thirty-year plus experience of the person behind English in Context and the fact that one technological innovation after the other have been successfully integrated into the product offer we felt that this satisfied the critical case condition put forth by Yin [13]. A case study comprises several methods. This project draws on data collection techniques which include, semi-structured interviews with key informants, chains of conversations and participant observation.

At this time, only the initial interviews coupled with conversations and observation have been completed. An interview guide along the lines of the afore-mentioned research questions was used and the interviews were transcribed and coded for analysis. Additional information concerning English in Context has come from conversations with the language providers as well as with learners. One interview has also been carried out with an expert in a formal higher education setting where English is taught as a second language. 


\section{FINDINGS}

Initial findings are based on observation, chains of conversations and interviews. As mentioned previously, English in Context is a language provider that has moved from book-based in-class teaching and learning to the introduction of mobile applications followed by the development of a virtual campus for on-line teaching and is now preparing to supplement its product offer with the introduction of the Interactive Immersion Learning System $360^{\circ}($ IILS360 $)$. The latter being 3-D virtual reality immersive videos. All technological introductions have been successfully weathered to date. As this is often not the case, the "how" behind strikes us as of utmost importance.

The question of timely introduction cannot be sufficiently emphasized. As with any technology, if it is proposed ahead of its time the chance of success is limited. At the same time, once the technology is sufficiently widespread, particularly true in a competitive market, it's use is no longer seen as adding value but as run of the mill. In the case of English in Context its success seems intimately linked to having timed the introduction of each new technology at just the right time. This is best illustrated with the time-line shown below.

Table 2. Introduction of new technologies over time by English in Context

\begin{tabular}{l|l|l}
\hline \hline YEAR & TECHNOLOGY & MARKET MATURITY \\
\hline 2000 & MP3 & $\begin{array}{l}\text { Named coined in 1995, by 2000 a cultural phenomenon } \\
\text { the world over and just beginning to go mainstream with } \\
\text { early users }\end{array}$ \\
\hline 2010 & YouTube & $\begin{array}{l}\text { 2005 the first video was uploaded, end } 2009 \text { the 1 } \\
\text { billion daily world view mark was reached, and full HD } \\
\text { launched. The market was going mainstream }\end{array}$ \\
\hline 2017 & Smartphone apps & $\begin{array}{l}\text { The first smartphones were introduced in 2007, by 2010 } \\
\text { both Apple and Android had systems up and running on } \\
\text { phones and tablets. Here to the market was going } \\
\text { mainstream }\end{array}$ \\
\hline \hline
\end{tabular}

It is of interest to note that every time English in Context has appropriated a new technology it has been just as the technology was going mainstream so whilst on an upward growth curve meaning that: it was accessible to both the company as a provider and to its students; the price of the technology would have decreased; it was still early enough so as to stake a claim before other, larger providers took over the market allowing English in Context to keep ahead of the game. In answer to our question of how best to navigate the introduction of new technologies, it would seem that timing is of the essence.

We also explored barriers to technology and this at the level of both the provider and also at the student level. From discussions and interviews, our initial reading is that of the four variables previously mentioned those of Performance Expectancy and Effort Expectancy seem to have more of an influence than do the others on the student. Whereas, the Social Influence variable seems to be of more importance for providers. These findings remain to be confirmed, however.

In terms of real barriers, it is not the technology itself that seems to come in question rather ease of access and use and, also that of cost. Here too, the importance of a well-timed introduction allows these barriers to be easily overcome.

\section{DISCUSSION \& CONCLUSIONS}

Although only at the early stages of the research project we feel that there are important concepts that emerge from our preliminary analysis. In addition to what Abernathy and Utterback said some forty years ago "It is reasonable that the diversity and uncertainty of performance requirements for new products give as advantage in their innovation to small, adaptable organizations with flexible technical 
approaches and good external communications, and historical evidence supports that hypothesis" [7], and which still stands today, is the idea of timeliness. The introduction of a new technology to early on is often doomed to failure, waiting until the technology is just getting established and sufficient interest is shown by the market would seem to be ideal as it is at this time that a firm or an educational institute can differentiate in a way that learners and students can appreciate.

It is expected that the coupling of this idea of timeliness with the UTAUT variables will allow us, in the future, to propose a model that integrates a social element into the standard product or technology lifecycles and may give education providers, whether independents or schools, an even better way of gauging when best to introduce new technologies.

\section{ACKNOWLEDGEMENTS}

Particular thanks go to English in Context for having opened their doors and their hearts to us as well as to Dr. Particia Pullin for her expertise.

\section{REFERENCES}

1. Schwab, K., The Fourth Industrial Revolution. 2016, Switzerland: World Economic Forum.

2. $\quad$ GSV Advisors Education Sector Factbook 2012. 2012.

3. Adkins, S.s., The 2013-2018 Worldwide Digital English Language Learning Market. 2014, Ambient Insight.

4. Richards, J.C. and T.S. Rodgers, Methods in Language Teaching. Cambridge: Cambridge University Press.

5. Curran, P., et al., Methodology in Language Learning: T-kit, in T-kit, A. Dussap and P. Curran, Editors. 2000, Council of Europe: Brussels, Belgium.

6. Celce-Murcia, M., Language Teaching Approaches: An Overview, in Teaching English as a second or foreign language. 1991, Heinle \& Heinle: Massachusetts.

7. Abernathy, W.J. and J.M. Utterback, Patterns of Industrial Innovation. Technology Review, 1978. 80(7): p. 40-47.

8. Rogers, E.M., Diffusion of innovations. 3rd ed. 1983, New York: Free Press of Glencoe.

9. Venkatesh, V., et al., User Acceptance of Information Technology: Toward a Unified View. MIS Quarterly, 2003. 27(3): p. 425-478.

10. Venkatesh, V., J.Y.L. Thong, and X. Xu, Unified Theory of Acceptance and Use of Technology: A Synthesis and the Road Ahead. Journal of the Association for Information Systems, 2016. 17(5): p. 328-376.

11. Dwivedi, Y.K., et al. Re-examining the Unified Theory of Acceptance and Use of Technology (UTAUT): Towards a Revised Theoretical Model. Information System Frontiers, 2017. June.

12. Linden, A. and J. Fenn, Understanding Gartner's Hype Cycles. 2003, Gartner Inc.

13. Yin, R.K., Case Study Research: Design and Methods. 2nd ed. Applied Social Research Methods Series. Vol. 5. 2002, Thousand Oaks: Sage. 